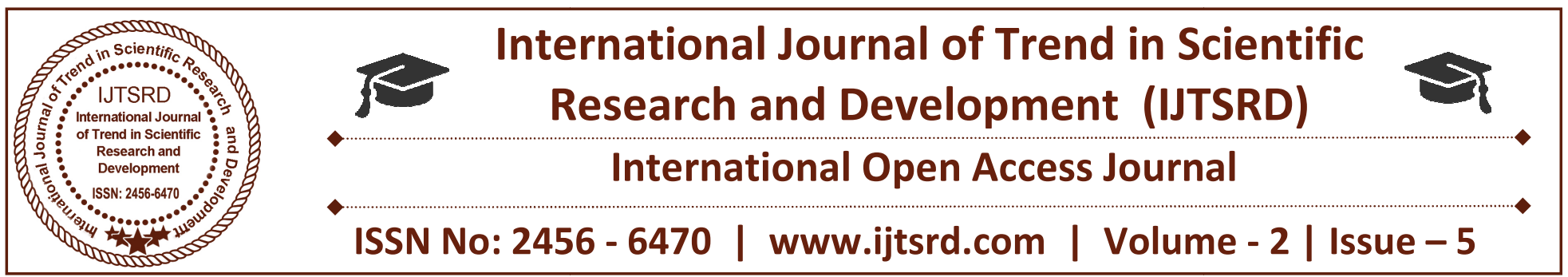

\title{
Problems and Reforms of Secondary Capital Market in India
}

\author{
Prasanta Kumar Dey \\ Associate Professor, Department of Commerce, Sir Gurudas Mahavidyalaya, \\ Ultadanga, Kolkata, West Bengal, India
}

\section{ABSTRACT}

Capital Market is vital for the growth and development of an economy. Now-a-days individual investors, mutual funds, pension funds and insurance funds place their money in various instruments of capital market. Therefore, sustainable and pragmatic development of capital market has become essential. With globalization of economies, the role of capital market regulator assumes more significant and the regulator has to be dynamic and responsive to challenges and changes not only to domestic but also to international ones. The most important issue to be kept in mind of the regulator is the traders and investors' interest. Regulation is not a static subject and it is a very dynamic one. Therefore, there is, sometimes, frequent review of securities laws to develop secondary capital market and protect interest of traders and investors - individual as well as institutional. Markets themselves are in a state of continuous development and so the contents of regulations must also change to facilitate proper regulation of the secondary capital market. Keeping in view the above objectives and principles, the Securities and Exchange Board of India (SEBI) has been framing regulations, guidelines and also changing them from time to time to make Indian capital market a modern, safe, fair and efficient one. For these reasons, several secondary capital market reforms have been introduced by the SEBI for the past several years to eradicate the challenges faced by secondary capital market in India.

Keyword: Capital Market, Investors, Oligopolistic, Problems, Reforms

\section{INTRODUCTION}

The capital market refers to the market for shares and bonds of the existing companies as well as those of new companies. This market is further divided into New Issue Market and Old Issue Market. The New Issue Market is also called primary capital market. The primary capital market is where the companies actually sale their shares and bonds first time to finance for investment projects. In nutshell, primary capital market is that part of capital market where dealing exchanges take place in the new capital issues i. e. Initial Public Offerings (IPOs) by existing and new companies. Likewise, the Old Issue Market is also called secondary capital market or stock exchanges where the existing investors, traders and prospective investors meet with each other. This means that the secondary capital market is the market for old and already issued securities. The secondary capital market is composed of industrial security market or the stock exchange in which industrial securities are bought and sold and the gilt-edged market in which the government and semigovernment securities are traded. Prior to the establishment of Securities and Exchange Board of India (SEBI) in 1992 as a statutory body, like in many other sectors of the economy, the capital market was also strictly regulated under a control and command regime. The raising of capital, pricing of issues and matters incidental thereto were controlled by the office of the Controller of Capital Issues (CCI) established under the Capital Issues Control Act,1947. In the budget speech of 1991-92, the then Finance Minister, Dr. Monmohan Singh, announced the repeal of the Capital Issues Control Act and transfer of powers from the CCI to the SEBI. This brought about a paradigm shift in the Indian Securities Market from control to disclosure based regulation. In this article, the various reforming activities with reference to secondary capital market are being discussed synoptically after mentioning the various age old 
problems and constraints suffered by the secondary capital market in India since its inception. Then, the reforms and their subsequent impacts are discussed in few words. The discussion of this article is ended with some concluding remarks with the view of its more efficient and vibrant secondary capital market in India.

\section{Major problems of secondary capital market in} India - This part of the article broadly covers the major challenges to the smooth functioning of the secondary capital market in India. These problems or barriers may be political, socio-economic or administrative in natures which are discussed here. Throughout the various phases, the secondary capital market in India has experienced growth and at the same time, some bottlenecks were also experienced. Some of them are mentioned as below:

1. Multiple regulations - Immediate after independence, some steps were taken to regulate the Indian capital market. During the postindependence phase, Indian Companies Act was passed in the year 1956. Before this, Capital Issues (Control) Act, 1947 also came into existence. Then Securities Contract (Regulation) Act was passed in the year 1956. Though the objectives of these acts were good, some provisions of these different acts were contradictory to each other. These multiple regulations also had negative impact on capital market developments.

2. Isolated stock exchanges - The stock exchanges in India have a presence only at particular locations. At the respective locations, normally trade takes place which is also characterized by regional features. But it must also be noted that stock brokers of one stock exchange were not allowed to operate in any other stock exchange. The stock exchanges were even not allowed to have branches at different locations. Due to this problem, only few stock exchanges like BSE dominated the trade in capital markets. But this had made other stock exchanges isolated. These stock exchanges were located in distant places throughout the country. But these regional stock exchanges were not much backed by volume of trading.

3. Lack of protection to investors -Though some laws were enacted during the earlier phase, there were no provisions ensuring investors' protection. There was no separate mechanism to look after grievances of investors. No guidelines were given for various players in the market. This was one of the reasons why there was still poor response from the households.

4. Open outcry - When the capital markets started functioning, few brokers used to come together at a particular place and perform trading activities. As the number of listed companies increased and number of brokers also increased, it was difficult to perform trading. Usually, some gestures and shouting was necessary to find the matching trade. For example, if one would have to purchase shares of X. Ltd. in a particular quantity at a specific rate, he had to shout and find another person willing to sell the shares of the same company and then, he could negotiate the prices. This system had a limitation that due to open outcry. Very few participants showed their interest in trading with this process. Further, this type of market is not suitable for genuine investors as they shy away from open outcry.

5. Problems faced during the post liberalization period (1991 onwards) - The two decades have lapsed after India accepted the globalization policy as a weapon for financial sector reforms. From restricted regime, slowly the economy moved towards open economy. Instead of control and restriction, the words management and development were used frequently. Even legal terminologies were also relaxed to some extent. By the year 1991, the number of listed companies was over six thousand which crossed eleventhousand marks in the year 2011. The market capitalization, daily trading volumes increased by leaps and bounds during the last two decades. As the private as well as foreign investment was allowed in various sectors, it provided a huge boost to the capital markets in India. If we look at the index numbers or share prices of companies, there has been huge upswing after 1991, after inception of financial sector reforms. But when all this was happening, there were some problems and constraints being developed in the financial market in general and capital market in particular.

6. Thin and restricted trading - In the stock exchanges, the number of hours for which trading is open for participants is very less 34 in a week. On an average only six hours of trading per day was permitted in the stock exchanges. Apart from this, there are number of holidays due to which an investor finds it difficult to have liquidity throughout a month. A study has observed that 
about $64 \%$ of the listed scrips were not traded at all on BSE during 1995-97.

7. Oligopolistic nature - Earlier, during the initial phases of development of capital market in India, BSE was the dominant stock exchange. Apart from this now NSE has taken over BSE, but collectively these two stock exchanges account for more than $90 \%$ of trades in stock exchanges. Membership of these exchanges is also restricted. The traders / brokers also speculate in shares without processing them. This hampers the general belief that capital market is a perfectly competitive market.

8. Excessive speculation - An excessive speculation in the stock exchanges has now become a well settled / established fact. Share prices in the market are determined by the speculative forces and these prices have very low references of fundamentals or performance of economy, industry or company. The dealers, merchants, insiders, fund managers etc. try to speculate the prices of share. As this has nothing to do with the performance of company, a genuine and studied investor tries to be aloof from the trading. This reduces the presence of genuine investors and thereby increases the speculative motive among the other market participants also.

9. Underdeveloped debt markets - The shares issued in the primary market are later on traded in the secondary markets i.e. stock exchanges. But a part of primary market also involves debenture financing. The debentures are issued in the primary market. But in stock exchanges there is no room for trading in debentures. The secondary market in industrial debentures remained underdeveloped over the years. Even though equity market has developed rapidly throughout the last two decades, the debentures market has remained underdeveloped. This results into less enthusiasm of long term investors in the market.

10. Scams in Indian capital market - After independence, a huge number of scams have been emerged in controlled regime of securities market of India. Some of the major scams in Indian stock markets are enlisted herewith - Harshad Mehta Scam - 1992, NBFC Ghotala - 1995-98, Plantation Companies Scam - 1997, Vanishing Companies Scam - 1999, Name Changing 'Game' - 2000, Dot com Scam - 2000, Ketan Parekh scam - 2001 and so on.

11. Unethical practices - Many unethical practices are rampant in Indian stock markets. Prices of shares are artificially increased before rights issues by circular trading. Gullible members of public who buy such shares find the prices of such shares dropping greatly and lose their money.

12. Misinformation - Funds are raised from investors promising investment in projects yielding high returns. But some promoters divert the money to speculative activities and other personal purposes. Investors who invest their money in such companies ultimately lose their money.

13. Absence of genuine investors - A very small proportion of purchases and sales affected in a stock exchange are by genuine investors. Speculators constitute a major portion of the market. Many of the transactions are carried out by speculators who plan to derive profits from short term fluctuations in prices of securities. This is evident from the fact that majority of the transactions are of the carry-forward type.

14. Fake shares - Frauds involving forged share certificates are quite common. Investors who buy shares unfortunately may get such fake certificates. They would not be able to trace the seller and their entire investment in such fake shares would be a loss.

15. Insider trading - Insider trading is a common occurrence in many stock exchanges. Insiders who come to know privileged information use it either to buy or sell shares and make a quick profit at the expense of common shareholders. Though many rules and regulations have been formulated to curb insider trading, it is a continuing phenomenon.

16. Prevalence of price rigging - Price rigging is a common evil plaguing the stock markets in India. Companies which plan to issue securities artificially try to increase the share prices, to make their issue attractive as well as enable them to price their issue at a high premium. Promoters enter into a secret agreement with the brokers.

17. Odd lots - Odd lots suffer from poor liquidity. The number of odd lot dealers is very less and odd lots have to be sold at a lower price.

18. Broker defaults - Due to excess speculation in specific shares, broker defaults occur. Such defaults destabilize stock exchanges and results in payment crisis.

Major reforms of secondary capital market in India -This section lists a host of reforms initiated for recovering the market structure and on its constituents. Several reforms have been introduced beginning with those in stock exchange 
administration, securities trading, settlement, delivery versus payment, securities transfer, trading in derivatives, risk reducing measures, screen based trading, investor protection fund and many more. A few of reforms have been analyzed in the following paragraphs:

1. Legal measures - Government of independent India adopted Capital Issues (Control) Act 1947 with the object to keep in existence the control over capital issues. Then, the Securities Contracts (Regulation) Act 1956 was enacted in order to prevent undesirable transactions in securities and to regulate the working of stock exchanges in the country. Finally, the Securities and Exchange Board of India (SEBI) was established in the year 1988 and given statutory powers on 30 January 1992 through the SEBI Act 1992 with the power for regulating the securities market in India. The preamble of the SEBI describes the basic functions of the SEBI as to protect the interests of investors in securities, to promote the development and to regulate the securities market.

2. Stock exchanges - Several important reforms were brought in stock exchange administration. Membership of governing boards of stock exchanges was changed to include 50 per cent outside representatives. The executive director who is a non-broker was also a member of the board in addition to the 50 per cent non-brokers. Generally non-broker representatives comprise members of judiciary, academicians, professionals such as Chartered Accountants, representative of Department of Company Affairs (DCA) and representatives of state governments. SEBI has constituted a group to review and examine the present structure of stock exchanges and examine the legal and financial issues involved in demutualising of stock exchanges. It will also advise on consolidation and merger of stock exchanges. It may be noted here that afterwards as per suggestions of this group, demutualization of some stock exchanges have been done.

3. Setting up of National Stock Exchange (NSE) NSE was set up in November 1992 and was owned by IDBI, UTI and other public sector institutions. It commenced its operations in 1994. NSE is a securities exchange which marks a radical break with the past. The regime in which trading on NSE operates is characterized by four key innovations (i) the physical floor was replaced by anonymous computerized order matching with strict price time priority, (ii) the limitations of being in Mumbai, and the limitations of India's public telecom network were avoided by using satellite communications, (iii) the NSE is not 'owned' by brokers as it is a limited liability company and brokers are franchisees and (iv) traditional practices of unreliable fortnightly settlement cycle with the escape clause of badla were replaced by a strict weekly settlement cycle without badla.

4. Changing pattern in trade - Indian stock exchanges have the history of more than one and a quarter century. Till 1994-95, stock trading was conducted in the open out-cry system. It was time consuming and ineffective. As volumes grew faster, the open out-cry system could not cope up with the demands of the investors across the country. Quite often the trading days were cut down and sometimes no trading took place on certain days. These disturbances created / increased liquidity risk and credit risk in the market place. As a result investors were losing faith in securities trading mechanism. In 1994-95, on line screen based (computerized) trading was introduced in India though Over-the-Counter Exchange of India (OTCEI) before 1992 but it was confined to small and newly listed companies. NSE for the first time, started screen based trading in equity shares across the country in 1995. It attracted the attention of the investors and they accepted the system. The stock exchange, Mumbai (BSE) also started computerized trading in shares. This was followed by all other exchanges. NSE opened its terminals in various towns and cities.

5. Screen based trading - In October, 1996 SEBI permitted other exchanges to expand their trading terminals to cities where there were no stock exchanges. As of now in over 400 cities and towns of the country trading terminals of major exchanges are available for investors. A major developmental initiative was a nation-wide on-line fully-automated screen based trading system (SBTS) where a member can punch into the computer quantities of securities and the prices at which he likes to transact and the transaction is executed as soon as it finds a matching sale or buy order from a counter party. Screen based trading makes on-line, electronic, anonymous and orderdriven transactions possible. It is a transparent system which provides equal access to all investors, irrespective of their geographical locations. SBTS electronically matches orders on a strict price / time priority and hence cut down on 
time, cost and risk of error, as well as on fraud resulting in improved operational efficiency. It allowed faster incorporation of price sensitive information into prevailing prices, thus increasing the informational efficiency of markets. It enabled market participants to see the full market on realtime, making the market transparent.

6. Investor Protection Fund (IPF) - All the stock exchanges are required to set up a fund called Investor Protection Fund (IPF). The purpose of the fund is to provide compensation to investors. The contribution to IPF is from members as a fraction of transaction charges, part of listing fees, interest on security deposits to be made by companies at the time of public issues etc. The amount of compensation available against a single claim of an investor arising out of default by a member broker of a stock exchange is Rs. one lakh in case of major stock exchanges, Rs. 50,000 in case of medium size stock exchanges and Rs 25,000 in case of smaller stock exchanges. However, BSE provides compensation up to Rs. ten lakh from this fund.

7. Trade Guarantee Fund / Settlement Guarantee Fund - For ensuring smooth completion of settlements, the stock exchanges have set up Trade Guarantee Fund (TGF) / Settlement Guarantee Fund (SGF). Twelve stock exchanges established Trade / Settlement Guarantee Fund. NSE is having a Clearing Corporation for settlement purpose. The existing trades guarantee funds set up by stock exchanges provide counter party guarantee for all the transactions which take place on stock exchanges and meet the payment obligations of the brokers immediately without waiting to declare them as defaulters. This means that the settlement (Pay-in and Pay-out) is effected immediately and investors get their money without delay.

8. Surveillance System - Exchanges were asked to set up independent surveillance cells directly under the Executive Directors of exchanges. The concerned Exchange Executive Director is solely responsible for surveillance activities. Exchanges were asked to develop online monitoring system. Online surveillance system generates alerts including real time alerts to indicate abnormal activity (if, any) in trading.

9. Accounting period settlement - The Indian stock market has historically adopted accounting period settlement. The accounting period settlement indicates the system whereby the positions of brokers accumulated till the end of a specific accounting period are settled on the basis of netted out positions with respect to every security. The accumulation of position during the settlement period gave scope for speculative activities thus, increased the possibility of default by participants. To overcome the deficiencies of the accounting period settlement system, rolling settlement system was introduced in a phased manner.

10. Rolling settlement - In 1998 rolling settlement was introduced by SEBI on a voluntary basis and then it was made compulsory on a $\mathrm{T}+5$ bases in a phased manner. A time schedule for implementation of $\mathrm{T}+2$ rolling settlement as prescribe by SEBI is as follows:

\begin{tabular}{|c|c|c|c|}
\hline $\begin{array}{l}\text { Sl. } \\
\text { No. }\end{array}$ & Day & Time & $\begin{array}{l}\text { Description of } \\
\text { Activity }\end{array}$ \\
\hline 1 & $\mathrm{~T}$ & - - & Trade Day \\
\hline 2 & $\begin{array}{c}\mathrm{T}+1 \\
\mathrm{nd}\end{array}$ & By 11.00 am & $\begin{array}{l}\text { Confirmation of all } \\
\text { trades (including } \\
\text { custodial trades). } \\
\text { Facility of an } \\
\text { exceptional window } \\
\text { for late confirmations } \\
\text { would be made } \\
\text { available by the } \\
\text { exchanges. }\end{array}$ \\
\hline & & By $1.30 \mathrm{pm}$ & $\begin{array}{l}\text { Processing and } \\
\text { downloading of } \\
\text { obligation files to } \\
\text { brokers / custodians. }\end{array}$ \\
\hline \multirow{2}{*}{3} & \multirow{2}{*}{$\mathrm{T}+2$} & By $11.00 \mathrm{am}$ & $\begin{array}{c}\text { Pay-in of securities and } \\
\text { funds. }\end{array}$ \\
\hline & & By $1.30 \mathrm{pm}$ & $\begin{array}{l}\text { Pay-out of securities } \\
\text { and funds. }\end{array}$ \\
\hline
\end{tabular}

11. Dematerialization of shares - Traditional settlement system on Indian stock exchanges gave rise to settlement risk due to the time that elapsed before trades settled by physical movement of certificates. There were two aspects - the first aspect was relating to settlement of trade in stock exchanges by delivery of shares by the seller and payment by the buyer. The second aspect was relating to transfer of shares in favour of the purchaser by the issuer. This system of transfer of ownership was grossly inefficient as every transfer involved the physical movement of paper securities to the issuer for registration, with the change of ownership being evidenced by an 
endorsement on the security certificate. Besides, theft, mutilation of certificates and other irregularities were rampant and in addition, the issuer had the right to refuse the transfer of a security. All these added to the costs and delays in settlement, restricted liquidity and made the grievance redressal of investors' time consuming and at times intractable. All these problems have been solved by setting up of depositories and introduction of scrip less trading. As per Depository Act, 1996 in November 1996, National Securities Depository Limited (NSDL) was set up as the first depository in India. Subsequently, in February, 1999, the Central Depository Services Limited (CDSL) was promoted as the second depository in India. Initially all institutional investors having a portfolio worth more than Rs. 10 Crore were required to trade and settle eight scrips namely of Bank of India, ICICI, IDBI, IPCL, Reliance Industries, SBI, L\&T and TISCO only through the electronic route with effect from January 15, 1998. Gradually the list of scrips for compulsory dematerialized trading was expanded to 12 w.e.f. Jan 4, 1999 to 19 w.e.f. Feb 15,1999 , to 33 w.e.f. April 5, 1999 and to 40 scrips with effect from May 31, 1999. Today, most of the trading (about $99.5 \%$ of transactions on BSE) are in the dematerialized (popularly called Demat) form.

12. Allowing large variety of participants - Capital markets are said to be more efficient when they have more participants, instruments, processes and other alternatives. Indian capital market was dominated by individual investors till early part of the 1990s. Earlier institutional investors such as Life Insurance Corporation of India, General Insurance Corporation of India and its four subsidiaries, Development Financial Institutions and Banks etc. used to take minor role in the capital market activity. Unit Trust of India, the only mutual fund then, used to play active role in the primary and secondary capital market. 1990s saw entry of many new participants to the capital market. SEBI permitted private sector and joint sector mutual funds. Government of India and SEBI allowed Foreign Institutional Investors, Non Resident Indian and Overseas Corporate Bodies to trade in securities in Indian capital market. Additionally, Non- Banking Finance Companies also have been taken interest in dealing in securities.
13. Introduction of derivatives trading - All the developed economies and capital markets have financial derivatives trading on their exchanges that provides risk management tool to hedge the risk in the underlying market. In line with the developed economies and capital markets, in Indian capital market also such derivatives trading have been permitted. Currently on two premier stock exchanges of our country i.e. on BSE and NSE, trading in four types of derivatives products namely, Index Futures. Stock Futures, Options on Index and Options on Stocks are in operation.

14. Corporate governance code - To maximize shareholders value and increase investors' confidence, SEBI has introduced the Corporate Governance Code for listed Companies and for the Companies which enter the market now through the listing agreement. As regards the accounting part of the corporate governance, the Institute of Chartered Accountants of India has already issued standards for Consolidation of Accounts, Segment Reporting, Related Party Transactions and Earnings per Share (EPS). The Indian Corporate Governance Code is one of the most comprehensive codes on the subject.

15. Investors' empowerment - Timely availability of quality and reliable information increases confidence of the investors in the market place. Over the past one decade, many regulatory requirements have been imposed on issuers, mutual funds and other constituents of the market to disclose relevant information to the public. Listed companies have to publish quarterly, half yearly and annual financial results as a condition for continued listing. Takeover code imposes restrictions to reveal acquisitions and extent of holding to enable other investors to take proper decision. Mutual funds publish daily net asset values, half yearly portfolio composition and other information. As part of public issue, the corporate publish issue-related information. This disclosure contributes to improve market efficiency.

16. Establishment of creditors rating agencies - Three creditors rating agencies viz. The Credit Rating Information Services of India Limited (CRISIL 1988), the Investment Information and Credit Rating Agency of India Limited (ICRA - 1991) and Credit Analysis and Research Limited (CARE) were set up in order to assess the financial health of different financial institutions and agencies related to the stock market activities. 
It is a guide for the investors also in evaluating the risk of their investments.

17. Increasing of merchant banking activities - Many Indian and foreign commercial banks have set up their merchant banking divisions in the last few years. These divisions provide financial services such as underwriting facilities, issue organizing, consultancy services, etc. It has proved as a helping hand to factors related to the capital market.

18. Insurance sector reforms - Indian insurance sector has also witnessed massive reforms in last few years. The Insurance Regulatory and Development Authority (IRDA) was set up in 2000. It paved the entry of the private insurance firms in India. As many insurance companies invest their money in the capital market, it has expanded.

19. Commodity trading - Along with the trading of ordinary securities, the trading in commodities is also recently encouraged. The Multi Commodity Exchange (MCX) is set up. The volume of such transactions is growing at a splendid rate.

\section{Conclusion}

A study of capital market significantly involves a study of problems which emerged in various phases of development of capital market in India. This article has presented these problems in a phased manner. Apart from this, an attempt has also been made to analyze the frauds which have taken place during last one and half century. The problems experienced in the Indian capital markets as well as the scams were significant as they proved to be hindrances in the smooth functioning of capital markets. Due to these hindrances a genuine investor has remained aloof from the market while more and more speculators and institutional investors continued to dominate the capital markets in India. This has also resulted into increased volatility in the Indian capital market. When the financial sector reforms were initiated, it was also emphasized to have a strong regulator for the Indian capital market. This task of regulation is being shouldered by SEBI to a great extent along with other regulators like RBI, Department of Company Affairs etc. Following the implementation of reforms in the secondary capital market in India in the past few years, Indian stock markets have stood out in the world ranking. But, there is more scope for further reforms and development.

\section{REFERENCES}

Books

1. Avadhani V. A.- "Investment Management", Himalaya Publishing House, Mumbai, 5th Revised Edition, 2002.

2. Bhaskara, P. Vijaya \& Mahapatra, B. (2003), Derivatives Simplified: An Introduction to Risk Management, Sage Publication, New Delhi

3. Majumdar, A. K. and Kapoor. G. K. (2005), Students' Guide To Company Law, Taxmann Publications (P) Ltd., New Delhi

4. Rao, N. K. (1988), Stock Market Efficiency: The Indian Experience. Reprinted in Gupta, O.P (1989): Stock Market Efficiency and Price Behavior, Anmol Publications, New Delhi

5. Sarkhel Jaydeb and Arindam Gupta (2002), Capital Market: Theory And Institutions, Book Syndicate Private Ltd.

6. Vashisht, A. K. \& Gupta, R. K. (2005), Investment Management and Stock Market, Deep \& Deep Publication Pvt. Ltd. New Delhi

7. Veena D. R.- "Stock Markets in India" - Ashish Publishing House, New Delhi.

Articles in Journals:

1. Vashistha, S. D., The Secondary Capital Market: Some Important Aspects, The Indian Journal of Commerce, Conference Issue (2001), Vol. 54 No. 4

2. Vijaysingh Thakur Devendrasingh, Emerging Issues in Capital Market, The Indian Journal of Commerce, Conference Issue (2001), Vol. 54 No. 4

3. Thakur, P. C. and J. Raghakardar Pal Singh, Reflections on the Changing Scenario of the Indian Stock Exchanges, The Indian Journal of Commerce, Conference Issue (2001), Vol. 54 No. 4 


\section{Reports}

1. Economic Survey (Various issues), Ministry of Finance, Government of India.

2. SEBI Annual Reports (Various issues), Department of Economic Affairs, Ministry of Finance, Government of India.

3. BSE Annual Reports

4. NSE Annual Reports

5. World Investment Reports

\section{Websites}

1. www.accountlearning.com

2. www.internationalconference.in

3. www.bseindia.com

4. www.capitalindia.com

5. www.capitalmarket.com

6. www.finmin.nic.in

7. www.indiainfoline.com

8. www.nseindia.com

9. www.sebi.gov.in

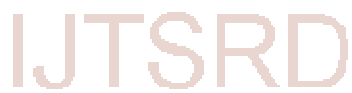
International Journal of Trend in Scientific Research and Development ISSN: $2456-6470$ 